Studia

Ecologiae et Bioethicae

Stanisław BIAŁY*

"Stara Europa, od Zachodu po Wschód, próbuje określić szuq nowq tożsamość. Nie można w tych poszukiwaniach zapomnieć o szooich korzeniach. Europa musi pamiçtać, że życiodajng limfa, z której przez dwa tysiqce lat czerpata najszlachetniejsze inspiracje duchozve, było chrześcijaństwo». ${ }^{1}$

\title{
Chrześcijańska sprawiedliwość społeczna kierunkiem dla rozwoju środowiska przyjaznego życiu
}

Sprawiedliwość (doskonałość) - demokratycznego państwa prawa ujętego jako środowisko życia społecznego ${ }^{2}$ - oto zagadnienie, które bardzo często pojawia się na ustach prawników, polityków, politologów czy legislatorów, ale także etyków, bioetyków, moralistów, teologów itp. Temat ten jest interesujący nie tylko dlatego, iż w takim systemie wypadło nam żyć, ale ponieważ musimy borykać się z wieloma problemami, które każą zastanowić się czy rzeczywiście «budowana» demokracja opiera się na wystarczająco zdrowych podstawach, tak aby można było powiedzieć, że wszyscy jesteśmy równi wobec tworzonego prawa i że jego normy są sprawiedliwe? ${ }^{3}$ Jeśli zatem chcielibyśmy dokonać etycznej refleksji nad teorią państwa i prawa, panującą w Unii Europejskiej (czyli fi-

* Instytut Studiów nad Rodziną, UKSW w Warszawie.

1 JAN PAWEL. II, Być świadkami Chrystusa dzisiaj, Przesłanie do uczestników Kongresu Katolików Świeckich Europy Wschodniej (8-12.10.2003), „Łomżyńskie Wiadomości Diecezjalne" 1 (2004) s. 6.

2 Por. T. PIKUS, $O$ w'tadzy w' kościele, Warszawa 2003, s. 104: tamże: «Można dokonać rozróżnienia między rządzeniem przez prawo a rządzeniem przez ludzi. Rządzenie za pomocą prawa jest uważane za ideał spoleczeństwa politycznego. Prawo oznacza, że ograniczenia rządu są dokładnie ustalone i z równą dokladnością są określone jego kompetencje».

3 Por. Nauki o rodzinie w' stużbie ew'angelizacji, red. K. Majdański i inni, Warszawa 1995, s. 21; tamże: «wykorzystując ignorancję religijną środowisk długotrwale administracyjnie ateizowanych, podsuwa się im modele życia jawne wrogie Ewangelii i narzuca niemożliwe do zrealizowania aspiracje konsumpcyjne. Skutkiem takich poczynań jest narastanie spolecznej frustracji, zatrata poczucia sensu życia i totalna beznadzieja». 
lozofią troski o nasze środowisko życia), ${ }^{4}$ której to dyrektywy na mocy różnych traktatów i umów są aplikowane do naszego rodzimego, narodowego, polskiego ustawodawstwa, to wydaje się, że można byłoby to uczynić poprzez ukazanie podstawowych zasad chrześcijańskiej koncepcji sprawiedliwości społecznej. Papież Jan Paweł II już od pierwszej swej encykliki Redemptor Hominis, przedstawia podstawy dialogu międzyludzkiego i międzynarodowego. Chodzi o zasady, które mają charakter uniwersalny: o pryncypium "pokoju», "solidarności», "sprawiedliwości», «wolności», "prawdy", i "miłości».

Jeśli w «epoce dialogu, negocjacji, porozumień i kompromisów zastanawiamy się nad istotnymi podstawami tych zjawisk», to temat ten wydaje się być szczególnie aktualnym z następujących powodów. Po pierwsze, 29 października 2004 r. został podpisany w Rzymie - przez 25 szefów rządów i państw europejskich - Traktat Konstytucyjny. Wydarzenie to budzi zaniepokojenie ze strony Stolicy Apostolskiej, która już wcześniej poprosiła o zrewidowanie konstytucyjnej preambuły, twierdząc że w ogóle Konstytucja w obecnej formie jest jeszcze nie gotowa, jako że nie uwzględnia kilku podstawowych kwestii dotyczących ochrony życia ludzkiego.? Po drugie, wciąż jesteśmy na różne sposoby indoktrynowani, iż rządy za pomocą prawa - stanowionego właśnie na zasadzie woli większości - są tym jedynym systemem, który może zapewnić bezpieczną i sprawiedliwą (pokojową) przyszłość.

Znana jest także niedawna wypowiedź jednego z przywódców polskich, który stwierdził iż «można być katolikiem bez zapisu o chrześcijaństwie w Konstytucji Europejskiej». Niestety dziś wiemy, że trzeba się liczyć z pewnymi konsekwencjami tego smutnego faktu. Przykładem może być tu sprawa Rocco Buttiglionego, który jako kandydat do Komisji Europejskiej zapłacił utratą stanowiska komisarza za odwagę wypowiedzenia na głos tego, co mówiło mu sumienie. Taki casus «to niepokojący precedens dla wszystkich chrześcijan pragnących uczestniczyć w życiu publicznym dzisiejszej Europy». ${ }^{8}$

4 Por. Y-M. HILAIRE, Prawa cztowieka, praw'a osoby, „Communio” 9 (1994) s. 208-209; tamże: «fundamentem naszej kultury politycznej jest mądrość grecka, prawo rzymskie i chrześcijaństwo. (...) Dzięki Arystotelesowi Grecy, poszukując owych ,lepszych rządów” (...) zaproponowali regułę większości, uważając, iż większe światło można znaleźć pośród większej liczby obywateli. (...) Rzymianie opracowali prawo pozwalające uznać wszystkie istoty ludzkie za podmioty prawne, lecz także przypisujące znaczną władzę cesarzowi. (...) Chrześcijanie idąc w ślad za Chrystusem, glosili równość wszystkich przed Bogiem oraz braterstwo wszystkich ludzi».

5 Por. J.M. DOłĘGA, Troska Jana Paw'ta Il o środow'isko, w: red. J. Sikora, 25 lat Pontyfikatu Jana Pawta II, „Episteme” 35 (2004) s. 160.

6 Tamże.

7 Por. www.andrzej.kai.pl.

8 P. SEMKA, Ukarane sumienie Rocco Butiglionego, „Rzeczypospolita” 27/10 (2004) s. 12. 


\section{Problem «braku» wlaściwego rozumienia sprawiedliwości społecznej}

Jeśli dziś podstawowym argumentem w dyskusji nad doskonałością systemu demokratycznego, podnosi się kwestię państwa prawa, które "zabezpiecza obywateli przed arbitralnym i niesprawiedliwym użyciem władzy», ${ }^{9}$ to trzeba powiedzieć, że już Tomasz Hobbes, który jest przecież zaliczany do "ojców» współczesnego państwa (teoria umowy społecznej), ${ }^{10}$ ostrzegał, że "któryż to człowiek mając zdrowe zmysły, choćby nie umiał ani pisać, ani czytać, nie rozumie, że nim rządzą ci, których się boi, co do których jest przekonany, że mogą go zabić, lub zrobić mu krzywdę, gdy się ich nie posłucha? Czyż myśli on, że prawo, to znaczy słowa i papier, może mu uczynić krzywdę, bez pomocy ludzkich rąk i mieczów?».11

Chodzi o to, że chociaż dziś za pomocą ustaw określa się różne obowiązki i przywileje obywatelskie, a rządzący mogą wymuszać posłuszeństwo do osiągnięcia określonych celów - jedynie prawem, to jednak można powiedzieć, że władzę posiada ten, kto wpływa na charakter i wymowę legislatury. Po prostu decyduje ten, kto ma władzę ustawodawczą, a najlepiej: ustawodawczą, wykonawczą i sądowniczą razem. W demokracji taki wpływ mają partie polityczne. A w Kościele? Tu też rządy «są bardziej rządami ludzi, a nie prawa, ponieważ są one formalnie i wyraźnie rządami braterskimi». ${ }^{12}$

Co więcej, posłuszeństwo obywateli stanowionemu prawu, wynika nie tyle ze strachu przed kara przez nie wyznaczoną, co z przekonania o jego wartości i słuszności. Chodzi o wcielane i urzeczywistniane ideałów wyznawanych przez ogół. Wyrazem tego jest choćby to, że już «od zarania cywilizacji formujące się grupy ludzi troszczyły się o to, aby zawierać porozumienia i pakty, które pozwoliłyby uniknąć samowolnego ucieka-

9 T. PIKUS, $O$ w'tadzy w Kościele, dz. cyt., s. 104.

10 Por. T. HOBBES, Lew'iatan czyli materia, forma i w'adza państw'a kościelnego i swieckiego, Krakótv 1954, wstęp s. 8: «widząc nieznośne a nieuniknione konsekwencje tej niczym nie skrępowanej wolności ludzie zawierają umowę społeczna, polegającą na tym, ze część, i to bardzo znaczną i istotną część swoich praw przenoszą na jednego czlowieka lub ciało zbiorowe, na suwerena, który za to zobowiązany jest zabezpieczyć im bezpieczeństwo życia i mienia. Tak powstaje państwo».

11 Por. Tamże, s. 610: «Jest więc to jeszcze jednym błędem polityki Arystotelesa, jakoby w dobrze urządzonym państwie nie ludzie winni rządzić, lecz prawa. (...) I błąd ten należy do liczby niebezpiecznych; takie bowiem błędy skłaniają ludzi do tego, że skoro tylko nie lubia swych władców, to przystają do tych, którzy owych władców nazywają tyranami».

12 T. PIKUS, $O$ wtadzy w' Kościele, dz. cyt., s. $104-105$; tamże: «Stanowiska zajmowane przez ludzi, którym dana jest władza w Kościele, nie są podobne do urzędów rządu świeckiego. (...) W Nowym Testamencie sam Jezus, a nie jakiś kodeks nakazów, zajmuje miejsce prawa w planie zbawienia». 
nia się do przemocy i dzięki którym można by podejmować próby pokojowego rozwiązywania narastających sporów». ${ }^{13}$ Tak więc: "obok przepisów prawnych poszczególnych ludów stopniowo tworzył się inny zbiór norm, który został określony jako ius gentium (prawo narodów)». ${ }^{14}$

Jest także znamienne, że wraz z powstaniem w Europie «nowoczesnych» państw, proces moralnego uzasadnienia, jeśli chodzi o posłuszeństwo prawu cywilnemu doznał wielkiego przyspieszenia. Od XVI wieku prawnicy, filozofowie i teologowie podejmowali trud opracowania różnych działów prawa «zakorzeniając je w fundamentalnych postulatach prawa naturalnego. Na tej drodze, ze wzrastającą mocą i zasięgiem, były formowane uniwersalne pryncypia, które są uprzednie i stojące ponad prawem wewnętrznych państw». ${ }^{15}$ Jednak to nie ustrzegło Europy przed zjawiskiem cywilnego nieposłuszeństwa oraz powstaniem wielu totalitarnych systemów i niesprawiedliwych wojen.

Także i dzisiaj rodzące się pytanie: jak przekształcić Unię Europejską $\mathrm{w}$ autentyczne państwo prawa, warunkujące trwałą jedność narodów? nie jest jedynie zagadnieniem retorycznym. W Polsce, ale i w całej Europie, nie cichnie spór o kształt Konstytucji Europejskiej, a tym samym o charakter stanowionego prawa, które powszechnie obowiązując, będzie nie tylko kształtować warunki naszego życia oraz następnych pokoleń, ale także wpływać na postawy (wybory, decyzje) ludzkie. Problem ten jest tym bardziej zasadny, iż w klasyczne pojęcie «prawa" czy "państwa prawa», zakładało uprzednie przyjęcie prawa naturalnego jako światła rozumu, którego zasady zostały tak wpisane przez Boga w ludzką naturę, iż jest ono znane jako oczywiste i powszechnie obowiązujące, niezmienne. Obecna - liberalna interpretacja prawa naturalnego - spadkobierczyni idei oświecenia, a za czym idzie pozytywizm prawny, po prostu stwarza realne zagrożenie, iż tworzone supermocarstwo $\mathrm{z}$ gwaranta praw człowieka, stanie się strukturą totalitarną. Niesprawiedliwość tworzonego $w$ tym systemie prawa wynika najzwyczajniej $z$ negacji prawdy o człowieku. ${ }^{16}$

Zatem podstawową kwestią, jaka stoi przed człowiekiem chrześcijańskiego sumienia jest, jak zdemaskować te przejawy niesprawiedliwości społecznej, które pod egidą demokracji i jej ideałów tolerancji i równo-

13 JAN PAWEL II, Zawsze aktualne zadanie: wychowywać do pokoju, Orędzie na XXXVII Światowy Dzień Pokoju 1 stycznia 2004, L’Osservatore Romano, wyd. pol. 2 (2004) s. 5.

14 Tamże.

15 Tamże; por. Elementi di diritto pubblico, red. S. Di Iorio, Napoli 1998, s. 13; tamże: «prawo konstytucyjne (Wielka Brytania od XII w., Francja od Rewolucji w 1789 r., inne kraje Europy XIX/XX w.) ma za przedmiot, strukturę państwa, funkcjonowanie organów konstytucjonalnych, oraz podstawowe pryncypia systemu politycznego w państwie».

16 Por. G. CATALDI, La convenzione del Consiglio D'Europa sui diritti dell'uomo e la biomedicina, in: Bioetica e diritti dell'uomo, red. L. Chieffi, Torino 2000, s. 267. 
uprawnienia, wdzierają się do naszych rodzimych struktur prawno-obyczajowych? ${ }^{17}$.

\section{1. Czy Kościół powinien publicznie krytykować? ${ }^{18}$}

Wydaje się, że nie można mówić o fundamentalnych regułach postępowania społecznego, bez odniesienia się do pojęcia sprawiedliwości, której korzenie zakotwiczone są w najgłębszych pokładach osoby ludzkiej, to jest w jej dążeniu do prawdy. Niestety, pojęcie sprawiedliwości, na jakie często powołuje się współczesny człowiek, budzi ambiwalentne uczucia u chrześcijanina, który choćby dowiaduje się $\mathrm{w}$ mass mediach - $\mathrm{o}$ wielkiej radości rodziców, którzy po latach starań doczekali się dziecka, które przyszło na drodze zapłodnienia «in vitro». Gdy czyta on pochwaly zanoszone na rzecz lekarzy, którzy tego «szlachetnego» dzieła z poświęceniem zawodowym dokonali. Rodzi się zatem pytanie, czy rzeczywiście ludzie dziś nie rozumieją, czy też nie chcą rozumieć, jak wielką krzywdę wyrządzają, podejmując się tego typu działań.

Przykład, jaki tu został podany, niestety jeden $z$ wielu, prezentuje $w$ istocie problem tworzenia i rozumienia prawa cywilnego, a tym samym kształtowania mentalności i obyczajów w oderwaniu od pełnej prawdy o człowieku, szczególnie w wymiarze jego nadprzyrodzonej godności. Negacja prawdy w ustawodastwie cywilnym, która jako taka jest dostępna $\mathrm{w}$ «naturalny» sposób każdemu człowiekowi jako wynik racjonalnego poznania, nie wykluczając tej, która została potwierdzona objawieniem w Chrystusie, jest czymś niezrozumiałym dla kogoś, kto pojmuje sprawiedliwość jako fundamentalną zasadę $w$ ochronie praw człowieka. ${ }^{19}$ Już tak jest, że w swoim sumieniu za prawdę wszyscy ludzie są odpowiedzialni, a uznanie jego «praw stanowi pierwszą zasadę wszelkiego porządku politycznego prawdziwie wolnego". ${ }^{20}$

Nie dziwi zatem, że Kościół jako nieugięty rzecznik sprawiedliwości - rozumianej jako nakaz Chrystusowej Ewangelii - zdecydowanie przestrzega przed racjonalistyczną koncepcją autonomii człowieka - «europejczyka». Nie może czynić inaczej w sytuacji, gdy próbuje się opierać wartości już nie tyle na przyrodzonej godności człowieka, ile po prostu na

17 Por. E. ROBEK, Sitq pokoju - prawda. Moc prawdy: wiara, nadzieja, mitośc, w: Problematyka pokoju u papieży Jana XXIII i Jana Pawla II, Ząbki 2004, s. 245.

18 Por. P. SEMKA. Ukarane sumienie Rocco Butiglionego, art. cyt., s. 12; tamże: «Parę miesięcy temu szwedzki pastor Ake Green został skazany na miesiąc więzienia za moralną krytykę homoseksualizmu. Incydent nie wywołał w Europie żadnej reakcji ani dyskusji».

19 Por. H. SKOROWSKI, Prawa czlowieka w' stuzbie pokoju w' nauczaniu Jana Pawta II, w: Problematyka pokoju u papieży Jana XXII i Jana Pawla II, red. J. Lewandowski, Ząbki 2004, s. 178.

20) JAN PAWEL II, Encyklika Centesimus annus (CA) 29. 
«na subiektywnych umowach społecznych».21 Bowiem, to musi prowadzić, czego zresztą jesteśmy świadkami, do wyłonienia się poglądów sprzecznych nie tylko z Objawieniem Chrystusowym (antychrześcijańskie), ale nawet $z$ samą naturalną etyką. Taki stan rzeczy nie może na długo zapewnić wewnętrznego czy międzynarodowego pokoju.22

Jeśli jest prawdą, że «na przestrzeni wieków wkład doktrynalny, jaki wniósł Kościół - szczególnie przez refleksję filozoficzną i teologiczną licznych myślicieli chrześcijańskich - w ukierunkowanie prawa międzynarodowego na dobro wspólne całej rodziny ludzkiej, był znaczący», to i dziś «moralność winna przyczyniać się do rozwoju prawa, ukierunkowując prawo na to, co jest sprawiedliwe i słuszne». To prawo naturalne, które "rządzi zasadami współżycia poszczególnych obywateli między sobą, powinno kierować wzajemne stosunki między państwami» ${ }^{23}$.

\section{Chrześcijańskie pojęcie sprawiedliwości społecznej - prawo środowiskiem życia czlowieka}

Społeczny charakter ludzkiej egzystencji sprawia, że sprawiedliwość jest źródłem całego porządku moralnego, fundamentalnym pryncypium współbytowania całych społeczeństw i narodów. ${ }^{24}$ Jeśli dziś mówi się o kryzysie państwa, o korupcji, o strukturach zła, o nieposzanowaniu praw człowieka itp., to na pytanie - dlaczego tak się dzieje, wielu myślicieli odpowiada, iż $w$ centrum problemu nie tyle znajduje się sprawa produkowania coraz to doskonalszego prawa (tak, aby niemożliwościa było je obejść), ale chodzi o trudność, jaką posiadają współczesne społeczeństwa, w zrozumieniu sensu sprawiedliwości. Bowiem, jeśli współczesne państwo prawa wzrosło na bazie obywatelskiego kontraktu, gdzie ustalano podział obowiązków i przywilejów na podstawie prawa naturalnego, to dzisiaj zaczyna być ono budowane na sprawiedliwości, rozumianej jako wytyczna zysków i interesów. ${ }^{25} \mathrm{~W}$ istocie jest tak, że to pozytywistyczne, neopozytywistyczne czy materialistyczne tendencje kultury świeckiej

21 Por. Nauki o rodzinie w stużbie ewangelizacji, dz. cyt., s. 22; tamże: «wystarczy pomyśleć o dramacie aborcji, o nadużyciach inżynierii genetycznej, o zamachach na życie i godność człowieka».

22 Por. J. PRZYBYLOWSKI, Rola Kościoła w wychow'aniu do pokoju, w: Problematyka pokoju u papieży Jana XXIII i Jana Pavła II, red. J. Lewandowski, s. 215.

23 JAN PAWEE II, Zaw'sze aktualne zadanie nychow'ywać do pokoju, Orędzie na XXXVII Światowy Dzień Pokoju, dz. cyt., s. 7.

24 Por. Tenże, Bez sprawiedliw'ości nie ma mitości (Senza giustizia non c'e' amore). Audiencja generalna, Watykan 8.11.1978, Insegnamenti, (Nauczanie Jana Pawla II - wydanie wloskie), I (1978) s. 109.

25 Por. L. BAGOLINI, Giustizia e societa', Roma 1983, s. 24. 
coraz bardziej zaciemniają ideę sprawiedliwości, prowadząc do zastąpienia jej władzą, ideologia czy wolnością. Po prostu dochodzi do zagubienia stałego punktu odniesienia w podejmowaniu jakiejkolwiek decyzji.

$Z$ tego to powodu, postaramy się ukazać jakie są ontologiczne fundamenty zasady sprawiedliwości. To powinno pozwolić na ukazanie nie tylko jej sensu, ale także sposobu rozstrzygania o jej treści. Jest to bardzo ważne, jeśli chcemy podjąć próbę skonfrontowania niektórych zapisów Traktatu Konstytucyjnego z obiektywnymi wymogami prawdy o człowieku. Unia Europejska, jak zdeklarowała, będzie dążyć «do osiągnięcia swych celów właściwymi środkami, w zależności od zakresu kompetencji przyznanych jej na mocy Konstytucji», ${ }^{26}$ jednak nie odpowiada dokładnie na pytanie, jakie będzie stosowała do tego środki? Bowiem jeśli chcemy podkreślić, że «sprawiedliwość jako nieodzowną przestrzeń uszanowania człowieka w jego godności i podmiotowości gwarantują podstawowe prawa człowiekan, ${ }^{27}$ to także musimy wiedzieć, że to tylko właściwe zrozumiane pojęcie sprawiedliwości może zagwarantować, iż nie zostaną one wypaczone, gwarantując przywileje tym, którzy są lepiej zorganizowani lub głośniej krzyczą.

\section{1. Granice sprawiedliwości}

Pomimo że "żadna ludzka działalność nie stoi poza sferą etyczną", ${ }^{28}$ to jednak warto zastanowić się nad zasięgiem (granica) sprawiedliwości, która jako podstawowa norma etyczna, jest racjonalnym i wolitywnym przekonaniem, co do konieczności ustalania należnych relacji międzyosobowych. Na tej bazie tworzą się stosunki pomiędzy człowiekiem a jego bliźnim, dobrem wspólnym, władzą, społeczeństwem itp. ${ }^{29}$ Jest to reguła współżycia społecznego tak głęboka i zasadnicza, że staje się wartością, dla której człowiek żyje oraz dzięki której życie ma jakiś sens. Jej zadaniem jest poprawnie zdefiniować, co jest należne każdemu od wszystkich i w tym samym czasie, wszystkim od każdego, co jest należne człowiekowi od człowieka, w różnych systemach i okolicznościach. ${ }^{30}$

26 Por. Konstytucja Europejska, art. I-3, 5, zobacz, art. I-2; tamże: «Wartości Unii. Unia opiera się na wartościach poszanowania godności osoby ludzkiej, wolności, demokracji, równości, państwa prawnego, jak również poszanowania praw człowieka, w tym praw osób należących do mniejszości. Wartości te są wspólne Państwom Członkowskim w społeczeństwie opartym na pluralizmie, niedyskryminacji, tolerancji, sprawiedliwości, solidarności oraz na równości kobiet i mężczyzn". H. SKOROWSKI, Prawa cztowieka w' stuzbie pokoju w' nauczanilu Jana Paw'ta II, art. cyt., s. 179.

28 JAN PAWEł. II, Ecyklika "Pacem in terris" - nieustanne zobowiqzanie, Orędzie na XXXVI Światowy Dzień Pokoju, L’Osservatore Romano, wyd. pol., 2 (2003) s. 7.

29 Por. Katechizm Kościoła Katolickiego, wyd. 1994 (KKK) 1807; 1928-1929.

3.) Por. JAN PAWEŁ II, Bez spran'iedliwości nie ma milości, dz., cyt., s. 109. 
Jednak $\mathrm{z}$ powodu przygodności tego świata, ustanowienie relacji $\mathrm{w}$ pełni sprawiedliwych jest czymś bardzo trudnym. Sprawiedliwość jako taka jest "większa" od człowieka, dotyka wymiarów życia nadprzyrodzonego - wiecznego. Jednakże pewną formę sprawiedliwości można osiągnąć już na ziemi. Poszukując jej, istota ludzka otwiera się na Boga, i w końcu to Jego odkrywa jako pełną Sprawiedliwość. Po prostu, każdy żyje i umiera $w$ jakimś niedosycie sprawiedliwości, bowiem ten świat nie jest $w$ stanie zaspokoić do końca kogoś, kto jest stworzony na obraz Boga. ${ }^{31}$

Pomimo ciągłych klęsk ponoszonych na drodze realizacji sprawiedliwości, świat nadal pozostaje zachwycony jej ideałem i nie brakuje osób, które chcą o nią «bić się». Powstają partie, całe programy polityczne na rzecz człowieka i społeczeństwa. $W$ istocie, chociaż ta chęć działania $w$ celu jej promocji i obrony nie jest ślepa, to jednak nie zawsze się pamięta, iż tylko sprawiedliwość zbudowana prawdzie o człowieku, może być autentycznym fundamentem pod zaangażowanie się $w$ obronę praw człowieka, czyli pod wskazanie obowiązków i uprawnień każdego i wszystkich razem. To prawda jest tą granicą, której sprawiedliwość przekroczyć nie może.

\section{2. Sprawiedliwość widziana jako wymóg prawdy}

Zasada sprawiedliwości, jeśli nawet prezentuje się jako dyspozycja i wymaganie racjonalności i woli ludzkiej, to ma jeszcze inny aspekt. Chociaż jest ona zdolnością intelektualną, która kieruje się obiektywną prawdą, jednak to sama prawda proponuje się człowiekowi w taki sposób, że ten staje się zdolnym do podporządkowania jej swoich decyzji tak dalece, że z niej czyni sobie fundamentalną regułę życia. To znaczy, nawet jeśli sprawiedliwość jest dyspozycją poddającą ludzkie działania wynikowi racjonalnego poznania, to tylko dzięki poznanej prawdzie nie jest ona ślepym mechanizmem działalności człowieka. Innymi słowy, zasada sprawiedliwości urzeczywistnia się na bazie imperatywu prawa naturalnego, który brzmi: «czyń dobrze», ale już siła nakazu, aby dać każdemu to, co się jemu należy, opiera się na przekonaniu opartym na doświadczeniu moralnym, na pewności, że realizacja prawdy daje sens, pełność i piękno życiu ludzkiemu.

Pytanie o prawdę wynika $z$ wierności swemu sumieniu, stąd też unikanie jej wskazań stanowi jakby zdradę samego siebie. Treść prawdy jest czymś, co objawia godność ludzką, a zastosowane jej w praktyce, staje się źródłem wolności człowieka. Niedbalstwo w jej poszukaniu prowadzi

31 Por. Tenże, Benedetta questa Nazione se fa della giustizia la strada maestra. Przemówienie papieża Jana Pawla II w Nowej Zelandii 24.11.1986, Insegnamenti, IX (1986) s. 1584-1590; zobacz: D. Composta, I fondamenti ontologici del diritto, Roma 1994, s. 292-304. 
do zaślepienia duchowego, a w konsekwencji do podeptania praw ludzkich. Prawda, która jest często nazywana «najwyższym dobrem człowieka», «światłem rozumu», «źródłem wolności», odpowiedzią jak rozróżniać dobro od zła», "prawem bożym, które mówi w sumieniu jako siła normatywna", ${ }^{32}$ ostatecznie Bóg jest najwyższą prawdą, ${ }^{33}$ jest tą wartością, iż szukanie jej i życie nią, nie oznacza nic innego, jak tylko oddanie sprawiedliwości tej rzeczywistości, z którą człowiek jest w kontakcie. Innymi słowy; sprawiedliwości możemy nazwać wymaganiem prawdy albo po prostu jej aplikacją do konkretnego przypadku działania, bowiem całe postępowanie człowieka jest moralne dobre pod warunkiem, że jest zorientowane naprawdę. Wiemy, że «wykroczenia przeciw prawdzie przez słowa lub czyny - wyrażają odmowę zobowiązania się do prawości moralnej». ${ }^{34}$

Prawdziwy charakter sprawiedliwości objawia się najpełniej poprzez brak poszanowania prawdy w życiu (społecznym). Z negacji prawdy rodzi się totalitaryzm, przemoc, zło. Całe dobro wspólne ma ją za fundament. Nie byłoby możliwe pokojowe współżycie obywateli, jeśli nie istniałby stały punkt odniesienia, gwarantujący sprawiedliwe stosunki pomiędzy ludźmi. Jeśli ludzie nie pokładaliby ufności w sprawiedliwość i nie mówiliby sobie prawdy. Jeśli ta nie byłaby respektowana. «Na poziomie odpowiedzialności państwowej i instytucji międzynarodowych, czynić prawdę oznacza: konstruowanie nowego, bardziej sprawiedliwego porządku na świecie». ${ }^{35}$ "Człowiek stworzony na obraz i podobieństwo Boże nie może żyć i rozwijać się bez lub przeciw prawdzie, po prostu umiera». ${ }^{36} \mathrm{Z}$ tego to powodu wymogiem sprawiedliwości jest, aby ciągle poszukiwał on prawdy, a mając ją raz znalezioną według niej postępował. ${ }^{37}$

Zatem jest czymś oczywistym, że afirmacja prawdy w jej obiektywnym - ontologicznym bycie, i w jej wiążącej mocy wobec sumienia, pozostaje podstawowym warunkiem właściwego zrozumienia, czym jest i jak funkcjonuje sprawiedliwość. Jak też «istnieje nierozerwalny związek pomiędzy zaangażowaniem na rzecz pokoju a poszanowaniem prawdy», ${ }^{38}$ tak samo musi istnieć identyczna współzależność między tymi rzeczywistościami a zasadą sprawiedliwości.

32 KKK 2468; por. Deklaracja Dignitatis Humanae 2; Św. Tomasz z Akwinu, STh II-II (58) 1; M. Cozzoli, Il settimo comandamento, w: Catechismo della Chiesa Cattolicca. Testo integrale e commento, Casale Monferrato 1993, 1094-1107.

33 Por. JAN PAWEE II, Encyklika Veritatis Splendor (VS) 22.

34 KKK 2464.

35 JAN PAWE⿺ II, La verita' forza della pace, Przestanie na XII Światowy Dzień Pokoju, Watykan 18.12.1979, Insegnamenti, II (1979) s. 1450-1451.

36 Tenże, Homilia, Al pellegrinaggio polacco, „L'Osservatore Romano” 29/30 (1990) s. I.

37 Por. VS 34

38 Tenże, Ecyklika «Pacem in terris» - nieustanne zobowiqzanie, Orędzie na XXXVI Światowy Dzień Pokoju, dz. cyt., s. 7. 


\section{3. Sprawiedliwość rozumiana jako zobowiązanie do miłości}

Sprawiedliwość, rozumiana jako podstawowa zasada regulująca sprawę stosunków państwo - obywatel, nazywana jest często: społecznqq. Ułożenie właściwego porządku wspólnotowego zostało zadane człowiekowi jako warunek gwarancji i poszanowania godności każdej istoty ludzkiej. Jednak jeśli weźmiemy pod uwagę fakt, że zostało mu także zawierzone «przykazanie miłości Boga i bliźniego, jako przykazanie miłości społecznej»; że «została mu powierzona misja tworzenia nowej cywilizacji i nowej kultury, które opierałyby się o prawdę, sprawiedliwość, miłość i wolność», ${ }^{39}$ zmusza do postawienia pytania: jak można pogodzić milość ze sprawiedliwością. Pierwsza jest przecież bezcennym, duchowym darem, druga ścisłym obowiązkiem oddania bliźniemu tego, na co zasługuje?

W odpowiedzi należy podkreślić, że jeśli nawet sprawiedliwość ma pewne granice: «doświadczenie przeszłości i naszego czasu pokazuje, że sama sprawiedliwość nie wystarczy, co więcej, może prowadzić do zanegowania samej siebie», ${ }^{40}$ to nie można nie zauważyć, chociaż prawdą jest, że sprawiedliwość musi przygotować grunt dla milości, że to «tylko miłość może zapewnić wypełnienie sprawiedliwości».11 Świat, z którego wyeliminowano przebaczenie, które przecież wypływa z miłości, stałby się miejscem nieczułej sprawiedliwości, w imię której każdy przedstawiłby własne prawa w stosunku do drugiego. «Nie ma miłości bez sprawiedliwości. Miłość przerasta sprawiedliwość, ale w tym samym czasie, znajduje ona swą weryfikację $w$ sprawiedliwości. Nawet ojciec $i$ matka, kochając dziecko, muszą być sprawiedliwi wobec niego. Jeśli chwieje się sprawiedliwość, także miłość jest $\mathrm{w}$ niebezpieczeństwie». ${ }^{42}$

Sprawiedliwość nie wystarcza do kształtowania stosunków społecznych, ale tylko wtedy, jeśli się ją ogranicza do wymiaru prawa. Także milość nie można powiedzieć, że zatrzymuje się jedynie na sprawach materialnych, bowiem obejmuje ona sprawy duchowe, estetyczne, moralne itp. Zatem jeśli przedmiotem sprawiedliwości społecznej ma być zabezpieczenie dobra wspólnego, to przedmiotem miłości będzie miłość tego dobra. ${ }^{43}$ Stąd jeśli nawet czasami sprawiedliwość i miłość jawią się jako siły sprzeczne, to $\mathrm{w}$ istocie "stanowia dwa oblicza tej samej rzeczywistości, dwa wymiary ludzkiej egzystencji, które powinny się uzupełniać». ${ }^{44}$

39 JAN PAWEL II, Non possiano creare la salvezza da soli, Discorso a un'associazione austriaca, Watykan 28.04.1990, Insegnamenti, XIII (1990) s. 1051.

40) Tenże, Ecyklika Dives in misericordia (DM) 12.

41 Tenże, Solo l'amore puo' assicurare la pieniezza della giustizia, dz., cyt., s. 1615.

42 Tenże, Senza giustizia non c'e' amore, Audiencja generalna, Watykan 8.11.1978, Insegnamenti, I (1978) s. 110.

4.3 Por. E. COLOM, Chiesa, carita' e politica. Bolettino su alcune pubblicazioni recenti, Ateneum Theologico 9 (1995) s. 161.

44 JAN PAWEL II, Zaw'sze aktualne zadanie w'ychow'ywac do pokoju, Orędzie na XXXVII Światowy Dzień Pokoju, dz., cyt., s. 7. 
W obliczu powyższego - można postawić pytanie, jak wyjaśnić powszechność obowiązku miłości, rozumianej właśnie jako zasada społeczna?

\section{3. 1. Powszechny obowiązek milości}

Otóż - chociaż chrześcijanin mocą wiary odkrywa w osobie Chrystusa pełnię prawdy (fundamentalną normę działania), rozumiejąc przez to moralność jako odpowiedź na boskie zaproszenie "pójdź za mną", gdzie wymaganie miłości na wzór Jezusa jest możliwe do spełnienia tylko dzięki darom Ducha św.; to jednak naturalnym «instrumentem», który daje każdemu człowiekowi możliwość kochania, jest nie co innego jak tylko intelekt i wolność woli. Innymi słowy - już z samej natury rzeczy wiadomo, że winniśmy sobie szacunek idący tak daleko, iż w ostateczności powinien przemienić się on w miłość. Co więcej, laska nie zniewala natury, ale sprawia komfort dla pracy rozumu, umacnia wolę w dobrem. Nie powinno dziwić, zatem, że w ten oto sposób, miłość budowana na prawdzie, staje się obowiązkiem każdej istoty ludzkiej: wierzącej i nie wierzącej; przykazaniem do realizacji na każdym odcinku życia, bez wyjątku. ${ }^{45}$ W obliczu tak rozumianych wymagań sprawiedliwości, które raz dają się odkryć w świetle praw rozumu ludzkiego, drugi raz poprzez Objawienie, można $z$ całą pewnością postawić tezę, iż to wlaśnie "miłość» staje się miarą i sposobem jej realizowania - dla wszystkich ludzi i to bez wyjątku. Z tej to racji także prawo cywilne, jeśli tylko urzeczywistnia obowiązek wyboru i poszanowania prawdy, jest uwewnętrzniane i staje się wskazaniem sumienia. Co więcej, wprawdzie miłość nie jest kategorią prawną, i nie może być w ścisłym sensie tego słowa przedmiotem regulacji ustawowych, to jednak może być ustalony właściwy stosunek pomiędzy nią a prawem cywilnym. Chodzi o swego rodzaju "pojednanie», gdzie legislacja państwowa w perspektywie odpowiedzialności za dobro wspólne, powinna czynić sobie ze «sprawiedliwości sięgającej aż do miłości», niezmienny cel poszukiwania i realizacji swojej misji. W przykazaniu miłości, bowiem, zamknięte są wszystkie wymagania sprawiedliwości. Jesteśmy powołani do miłości społecznej - powie papież Jan Paweł II, "czyli do pracy do dobra wspólnego narodu, aby budować w nim coraz bardziej sprawiedliwość i zgodę, aby stwarzać warunki, w których poszanowane będą prawa człowieka». ${ }^{46}$

45 Por. Tenże, Reconciliazione e penitenza per liberare gli uomini, Anioł Pański, Watykan 14.03.1982, Insegnamenti, V (1982) s. 860-862.

4h Tenże, Encyklika Sollicitudo Rei Socialis (SRS) 38. 


\section{4. Sprawiedliwość a zasada solidarności i pomocniczości}

Norma sprawiedliwości jest również bardzo ściśle powiązana z zasadą solidarności i pomocniczości. ${ }^{47}$ Pierwsza jest zaangażowaniem się dla dobra bliźniego, nie na zasadzie jakiegoś współczucia, ale jako ścisły obowiązek wynikający z prawdy o człowieku, który ma prawo do bycia wspartym, gdy znajdzie się w potrzebie. Solidarność oznacza praktykę szacunku wynikającą z jednakowej godności wszystkich istot ludzkich, a także $z$ tego powodu, że dobra tej ziemi zostały powierzone przez Boga wszystkim ludziom. Innymi słowy, chodzi o charakter pracy ludzkiej, a także o "prymat osoby ludzkiej nad rzeczami». ${ }^{48}$

Bez ducha solidarności, nie jest możliwe skuteczne wymaganie, wzbudzenie czy realizowanie postawy ofiarności na rzecz dobra wspólnego. Zatem solidarność, której znaczenie moralne «ukazuje się jako jeden z fundamentalnych pryncypiów chrześcijańskiej koncepcji, na zorganizowanie się społeczne i polityczne», ${ }^{49}$ jest postawą i normą etyczną, która pozwala na fundamencie "przyrodzonej-nadprzyrodzonej» godności ludzkiej, opracować autentyczne pojęcie praw i obowiązków człowie$\mathrm{ka}^{50}$ Znajdując swe korzenie w prawdzie o człowieku oraz będąc budowana $\mathrm{w}$ duchu uniwersalnej postawy otwarcia się na bliźniego, staje się kryterium sprawiedliwości $w$ podejmowaniu decyzji, w wyborach prywatnych i społecznych.

Druga - pomocniczość (subsydiarność) - jest jakby bardziej skomplikowana, bowiem chodzi o właściwy stosunek państwa do grup społecznych, instytucji, stowarzyszeń itp. Polega ona na udzielaniu im umiejętnej pomocy w pełnieniu przez nie jakiś poszczególnych, konkretnych zadań. Chodzi o to, że liczne grupy, społeczności (narody) itp., mogą lepiej niż państwo rozwiązywać ich własne problemy, które są do załatwienia na poziomie lokalnym. Co więcej takie działanie może dać im dużą satysfakcję płynącą z możliwości kreowania własnego losu. Stąd grupy lepiej zorganizowane nie mogą mieszać się w taki sposób w życie wewnętrzne wspólnot będących na niższym poziomie organizacji, że będą pozbawiać je kompetencji..$^{51}$

47 Por. P. CZARNECKI, Recepcja zasady pomocniczości $w$ 40. rocznicę ogłoszenia encykliki Jana XXIII Pacem in terris, w: Problematyka pokoju u papieży Jana XXII i Jana Pawła II, red. J. Lewandowski, s. 289.

48 Por. Tamże 21, 38; JAN PAWEŁ II, Solo una nuova solidarieta' fondata sul vero significato del lavoro umano, Discorso tenuto alla LXVIII Sessione della Conferenza Internazionale del Lavoro, Szwajcaria 15.06.1982, Insegnamenti, V (1992) s. 2261.

49 CA 10.

50 Por. JAN PAWEL II, Sulla base del bene comune si sviluppa il senso dell'identita' naziona$l e$, Discorso tenuto all'inugurazione della XLII Settimana Sociale dei Cattolici Italiani, Watykan 21.09.1993, Insegnamenti, XVI (1993) s. 821.

51 Por. CA 36. 
Jeśli zatem zasada subsydiarności oznacza, że władza publiczna nie może zastępować inicjatywy obywateli, to na polu życia społecznego wyrażać się będzie ona jako swoista autonomia narodu. ${ }^{52} \mathrm{~W}$ ramach pracy jako pomoc państwa w tworzeniu korzystnych warunków dla wolnej aktywności ekonomicznej. ${ }^{53} \mathrm{~W}$ zakresie edukacji - jako pomoc ofiarowana rodzicom $\mathrm{w}$ trudnym zadaniu wychowawczym..$^{54} \mathrm{~W}$ dziedzinie kultury jako stymulacja do przeróżnych, adekwatnych inicjatyw kulturowych. W płaszczyźnie współpracy międzynarodowej - jako pomoc w poszanowaniu praw człowieka itp.

Wobec powyższego należy z mocą podkreślić, iż powyższe pryncypium wyrażając prymat osoby na państwem, tj., aby człowiek nie był ograniczany w swej wolności twórczej (w działaniu) do jakiejś roli wyznaczonej mu przez innych, także pozostaje ścisłym sprawdzianem rozumienia; czym jest sprawiedliwość, i jako takie powinno stać się ścisłym punktem odniesienia dla ustawodawstwa państwowego, tj., podstawowym kryterium dla sprawdzania uczciwości i autentyczności emanowanego przez państwo prawa.

\section{Sprawiedliwość a prawa człowieka}

Prawami człowieka nazywamy takie normy cywilne, które odpowiadaja na istotne potrzeby osoby ludzkiej. Chodzi o protekcję celu jakim jest życie i integralny rozwój człowieka, widzianego w wspólnocie czynników materialnych i duchowych. Wyrażają one i bronią tak ważne dobra człowieka, iż każda norma traci (powinna stracić) swą ważność (moralną), jeśli się im sprzeciwia lub je gwałci. Nie można bowiem pozbawić kogoś jego praw, bez dokonania gwałtu na jego godności i naturze. ${ }^{55}$ Są one tak oczywiste, że aby poznać które to są, wystarczy wymienić kilka z nich. Otóż mamy: prawo do życia, prawo do wolności sumienia, do wolności religijnej, do nauki, do pracy, do wiedzy, do uczestnictwa w życiu publicznym, do posiadania rodziny itp. Działają one tak, że stwarzają takie pole powinności. Po jednej stronie znajdują się uprawnienia, a po drugiej zobowiązania. Innymi słowy, regulują one międzyosobowe relacje, oparte na realizowanym dobru osoby ludzkiej.

52 Por. JAN PAWE⿺ II, L'unita' tipica dei vescovi polacchi, All'Episcopato polacco 5.06.1979, Insegnamenti, II (1979) s. 1432-1446.

53 Por. CA 15.

54 Por. JAN PAWEŁ II, L'insosituibile carattere educativo della Famiglia, Alla Confederazione ex alunni ed ex alunne della Scuola Cattolica, Watykan 26.02.1994, Insegnamenti, XVII (1994) s. 553.

55 Por. F. COMPAGNONI, Diritti dell'uomo. Genes, storiai e impegno cristiano, Milano 1995 , s. $84-85$. 
Jednak, zanim prawa te zostały skodyfikowane ustawowo, to były już wpisane przez Boga $w$ naturę istoty ludzkiej, wraz $\mathrm{z}$ darem istnienia. ${ }^{56}$ Człowiek ma za zadanie - jedynie - je poznać i respektować. Stąd nazywamy je: naturalnymi. Są one wymaganiami płynącymi z prawdy o człowieku, wyrażonej przede wszystkim głosem: «czyń dobro». Innymi słowy, jeśli prawo cywilne bierze je pod opiekę, to dlatego że są to racjonalne, realne byty, których treść jest formułowana przez analogię do poznanej prawdy o bycie ludzkim. To znaczy, jeśli życie ludzkie uznamy jako wartość podstawową i niezbywalną, zatem analogicznie można przypisać czlowiekowi prawo i obowiązek żądania, aby zostały zawieszone wszystkie działania wymierzone przeciwko jego życiu. Czyli nie zatruwano powietrza, ziemi, wody, aby pozwolono mu żyć od poczęcia do naturalnej śmierci itp. Taki racjonalny porządek ma miejsce we wspólnocie, nie dlatego że postanowił go jakiś prawodawca, ale dlatego że porządek ten jest częścią naturalnego prawa moralnego. Chodzi o należne dobro człowiekowi, tj., o ścisłą sprawiedliwość. Charakter tego dobra jest podstawą i mocą wiążącą tego prawa. ${ }^{57}$

Tak więc, naturalne prawa człowieka nabywają funkcji roszczeniowej w społeczeństwie zorganizowanym politycznie, kiedy pojawiają się jako normy prawa cywilnego (najlepiej, jeśli są chronione konstytucyjnie). «Konstytucjonalizacja tych praw miała spowodować, że prawa te $z$ ogólnych idei przekształcą się $\mathrm{w}$ wiążące normy prawne». ${ }^{58}$ Zatem prawa człowieka - pojęte jako byt relacyjny, należy rozpatrywać $\mathrm{w}$ dwu aspektach; egzystencjalnym - dotyczącym samego faktu istnienia prawa, i treściowym - oznaczającym zawartość tego prawa. Analogicznie do powyższego można powiedzieć, że choć mają one charakter prawa subiektywnego, to jednak kiedy zostaną ujęte przedmiotowo w normę cywilną (ustawową) - stanowią takie wymaganie, że jego nieposzanowanie grozi karą, określoną odpowiednim przepisem. ${ }^{59}$

Należy jednak podkreślić, że jeśli prawa takie obowiązują $\mathrm{w}$ celu ochrony dobra jednostki, to trzeba dodać, że $w$ jego realizacji muszą uwzględnić także zasadę dobra wspólnego. Innymi słowy, to co stanowi dobro wynikające $\mathrm{z}$ natury ludzkiej i prawo do niego, znajduje się $\mathrm{w}$ dynamicznej perspektywie. Owo dobro jest zamierzeniem egzystencjalnym danego człowieka, ale pozostaje zarazem czymś wspólnym dla każdej oso-

56 Por. Tenże, Encyklika Evangelium Vitae (EV) 69.

57 Por. EV 69-70; S. MICHALIK, Koncepcja wolności ponowoczesnej w' twórczości Zygmunta Baumana, „Etyka” 35 (2002) s. 54; tamże: tu «prawa, które określają współczesne pojęcie obywatelstwa społecznego, zakreślają granice nieingerencji państwa, wspólnoty, czy ludzi w ogóle, w życie jednostki, wyznaczając tym samym przestrzeń jej indywidualnej przestrzeni». P. Tuleja, Prawo naturalne i prawo pozytywne, „Ethos” 45/46 (1999) s. 28-209.

59 Por. M. A. KRĄPIEC, Prawo naturalne a praw'o pozytywne, w: Człowiek sumienia. Katechizm Kościoła Katolickiego. Część III, Olsztyn 1997, s. 126-127. 
by, która dąży do realizacji swych naturalnych inklinacji. Zatem nie jest moźliwe pozyskać go raz na zawsze, ale trzeba troszczyć się o nie, dbać, walczyć itp. Być może dlatego pojęcie praw człowieka często ewidencjonuje się w grupy. Mamy prawa wolnościowe (aby nie być przeszkodzonym przez osoby trzecie); solidarnościowe (uprawnienie do otrzymania wsparcia); cywilne, które realizują status obywatela i nie odnoszą się do człowieka jako osoby; trzeciej generacji itp. Znaczy to, że w swej bytowej podstawie moga być one zastosowane do każdego typu życia społecznego. Chodzi o to, że nawet prawo cywilne i prawo kanoniczne mają to samo źródło, jako że Objawienie chrześcijańskie jest tylko pogłębieniem tego, co z natury rzeczy powinno regulować życie społeczne. W głębi te dwa systemy - kanoniczny i cywilny - są współzależne, ponieważ «prawo w tym, co stanowi o jego istocie, jest synonimem sprawiedliwości, i jest jedno» ${ }^{60}$. Zatem, chociaż istnieje tylko jedna rzeczywistość prawa naturalnego, to istnieją różne sposoby jego wyrażania i aplikacji. ${ }^{61}$

\section{1. Nadprzyrodzona godność czlowieka jako uzasadnienie praw czlowieka}

W obecnym momencie naszych refleksji chcemy rozważyć, dlaczego nie powinno się dokonywać bezpośredniej dedukcji prawa pozytywnego (cywilnego) z naturalnego prawa moralnego (jak czyniono w uprzednich wiekach), ale należy znaleźć jakieś pryncypium, czyli taką ogólną zasadę, którą będzie można uzasadnić, dlaczego dane prawo obowiązuje, i to pod sankcją karną ${ }^{62}$.

\section{1. 1. Błąd bezpośredniej dedukcji}

W swej treści - naturalne prawo moralne - jest tak generalne, że objawia się w sposób pozytywny i bezpośredni jedynie w formie sądu rozumu praktycznego, który komunikuje: «dobro należy czynić, a zła unikać». Wszystkie inne symptomy naturalnego prawa moralnego nie mają wyszczególnionej, zdeterminowanej i pozytywnej treści. Pokazują jedynie ogólne kierunki działania ludzkiego, przyporządkowane naturalnym inklinacjom. To znaczy, że wie się z oczywistości rzeczy, że nie wolno zabijać, kraść, mówić fałszywie, zdradzać itp. Sa to imperatywy sumienia

60 JAN PAWEŁ II, Fedelta', esemplarita', senso della cattolicita', Przemówienie na Uniwersytecie Laterańskim, Rzym 16.02.1980, Insegnamenti, V (1980) s. 407.

61 Por. GS 23; Mówi się o tak zwanej kanonizacji praw cywilnych. Jest tak, kiedy prawo kanoniczne zamiast regulować pewne kwestie bezpośrednio, nakazuje stosowanie integralne lub częściowe, dyspozycji praw państwowych».

62 Por. E. KACZYŃSKI, Fondazione della morale nel pensiero contemporaneo, „Sapienza” 36 (1983) s. $309-310$. 
ludzkiego. Nakazy o takim ogólnym, generalnym charakterze nie mogą być bezpośrednio przełożone $w$ terminy prawa cywilnego, podobnie jak jest niemożliwe ustalenie konkretnych konsekwencji karnych za ewentualne jego nieprzestrzeganie. Np. pojęcie istnienia Boga jest zbyt generalne, aby wystarczało na określenie w sposób absolutny i bezpośredni szczegółowych treści etyki chrześcijańskiej. ${ }^{63}$

Innymi słowy, niemożliwość bezpośredniej dedukcji prawa cywilnego $z$ naturalnego prawa moralnego leży $w$ tym, że treści naturalnych praw człowieka (także sankcji) nie można wyrazić w terminach jednoznacznych. Robić to zatem należy na zasadzie analogii. Chodzi o to, że mimo iż nie można usprawiedliwić bezpośredniej dedukcji naturalnego prawa moralnego w cywilne, to istnieje silne powiązanie pomiędzy nimi. Po prostu, jest możliwe ukazanie negatywnych konsekwencji $z$ niezachowywania prawa naturalnego. Tak więc, chociaż naturalnego prawa moralnego nie powinno się ujmować bezpośrednio w spis prawa cywilnego, to jednak jest ono konieczną pomoca, bez której nie można obejść się, jeśli staramy się dać adekwatną odpowiedź na pytanie, jak ułożyć sprawiedliwie stosunki społeczne. Tak samo; odrzucenie prawa cywilnego jako takiego (anarchia) oznacza - obalenie naturalnego prawa moralnego mówiącego: «czyń dobro» ${ }^{64}$

\section{1. 2. Podwójna argumentacja godności człowieka - ostatecznym pryncypium uzasadniającym prawa czlowieka}

Obecnie nie ogranicza się podstawy praw człowieka do prawa naturalnego, ale szukając sposobu dla ich całkowitego wyjaśnienia - równolegle do pojęcia natury - stawia się ideę godności człowieka (obejmującą całą prawdę o osobie ludzkiej). Po prostu, naturalne prawa człowieka, jak i jego godność mają swe ostateczne umocowanie w Transcendencji (prawo nie mogłoby go do końca zobowiązywać, gdyby on sam sobie je nakładał). Prawda ta powinna mieć swe adekwatne odzwierciedlenie konstytucji, jeśli zapisane tam "prawa człowieka» mają być gwarancją dla autentycznej ochrony jego integralnego dobra.

Taka interpretacja nie powinna być pojmowana jako ta, która jest związana $z$ jednym kręgiem kulturowym. Musimy to jasno uznać, tak jak chcemy mieć skuteczną ochronę praw człowieka, i jak uznajemy jedność jego natury. ${ }^{65}$ "Istota ludzka, jeśli nie jest uznana i kochana na miarę jej

63 Por. M.A. KRĄPIEC, Cztowiek i prawo naturalne, Lublin 1986, s. 225-232.

64 Por. Tamże.

65 J. KRUKOWSKI, Przyrodzona godnośc osoby ludzkiej podstaw'a praw' cztowieka w' porzqdku międzynarodowym i konstyfucyjnym, „Ethos” 45/46 (1999) s. 197; tamże: «godność czlowieka polega na tym, iż jest istotą rozumną i wolną - stworzoną na „obraz i podobieństwo Boże”. Twórcy międzynarodowej ochrony praw czlowieka nie chcieli wszakże wiązać jej z jednym kręgiem kulturowym». 
godności żywego obrazu Boga (por. Rdz 1,26), narażona jest na najbardziej upokarzające i wynaturzone akty "uprzedmiotowienia”, w wyniku których dostaje się $w$ niewolę silniejszego" ${ }^{66}$ Praktycznym dowodem na powagę powyższych słów jest chocby następujący fakt. Otóż: Powszechna Deklaracja Prazu Człozvieka, w preambule zaznacza, że «uznanie przyrodzonej godności oraz wszystkich praw wszystkich członków wspólnoty ludzkiej jest podstawą wolności, sprawiedliwości i pokoju świata». Jeśli tak, to zapytajmy na czym ta sprawiedliwość polega, nikogo innego tylko ludzi pokrzywdzonych, którzy mimo i w imię powyższego (tak sformułowanego) zapisu, nie mogą dojść swych fundamentalnych praw.

Jest zatem do podkreślenia, że osoba ludzka widziana, czy to $z$ aspektu refleksji filozoficznej, czy to $z$ teologicznej, nie przestaje być istota, która została obdarzona wolnością: rozumem i wolną wolą. Owa sytuacja urzeczywistniająca godność osoby ludzkiej, stwarza sferę praw i obowiązków, które odnoszą się do każdego człowieka, bez wyjątku. Taka podwójna argumentacja prawa: typu filozoficznego i religijnego, ma ogromne znaczenie, jeśli chcemy wyrazić jego wspólną wartości dla całej wspólnoty ludzkiej: dla wierzących i poszukujących. Z takiej pozycji też nikomu, kto ma na uwadze autentyczną ochronę praw człowieka rezygnować. Jest to tak zwane "minimum etyczne». Jest znamienne, że Konstytucja Trzeciej Rzeczypospolitej Polskiej z 12.04.1997 r., tak formuje preambułę, aby mogli się pod nią podpisać zarówno wierzący w Boga, jak i nie wierzący. «Świeckość oznacza bowiem w pierwszym rzędzie postawę tego, kto szanuje prawdy mające swoje źródło w naturalnej świadomości człowieka żyjącego w społeczeństwie, chociażby te prawdy były jednocześnie głoszone przez określoną religię, a to dlatego że prawda jest jedna". ${ }^{67}$

Wszystko to jednak nie zabrania stwierdzić, że nawet konstytucjonalne uznanie pięknie brzmiącej zasady, iż szacunek i promocja godności osoby ludzkiej powinny przełożyć się na obronę i propagowanie jej praw i odwrotnie, nie wystarczy na uniwersalne zaakceptowanie wartości chrześcijańskich. Problem leży w szczegółach, a dokładniej w uznaniu całej prawdy o człowieku, bez której «szlachetne» demokratyczne ideały (państwa prawa) pozostaną martwe. ${ }^{68}$ Tak naprawdę kwestia leży w pytaniu, czy

\footnotetext{
66 Encyklika Christifideles Laici (ChL) 5; por. CA 13; zobacz: A. SZOSTEK, Prawo naturalne a praw'o stanowione. Uwagi etyka, „Ethos” 12 (1999) s. 160.

67 Kongregacja Doktryny Wiary, Nota doktrynalna dotyczqca pewnych kwestii zwiqzanych $z$ udziatem i postawa katolików' w życiu politycznym, Kraków 2003. s. 23.

68 Por. T. BARANKIEWICZ, Aksjologiczna problemaryka prawa, „Roczniki Nauk Prawnych” 14 (2004) s. 55; tamże: «problematykę wartości prawa można sprowadzić do sporu między pozytywizmem prawniczym a aksjologizmem prawniczym. Istnieją różne koncepcje i nurty obu stanowisk. (...) Pozytywista jest świadom, że (...) kryterium uznania czegoś za normę prawną leży po stronie prawodawcy, po stronie tego, „,kto stanowi”, a nie tego, ,co jest stanowione"».
} 
współczesny człowiek zechce spotkać się osobowo z Jezusem Chrystusem? Dowodem na to, że niektórym ludziom pomysł ten wcale nie odpowiada, jest właśnie naturalistyczna (liberalna) teoria praw człowieka. ${ }^{69}$

\section{Liberalna teoria praw człowieka a kwestia sprawiedliwości społecznej}

Jeśli twierdzi się, że doskonałość systemu społecznego zależy od sprawiedliwości panujących tam relacji, to trzeba powiedzieć, że w kulturze zachodniej lingwistyczne wyrażenie: "prawa człowieka", pojawiło się po raz pierwszy $w$ drugiej połowie XVII wieku, we Francji (pod innym imieniem były już wcześniej znane).$^{70}$ Także $w$ Unii Europejskiej pojęcie sprawiedliwości społecznej łączy się ściśle z prawami człowieka. Zatem, aby lepiej zrozumieć ich obecne pojmowanie (filozofię), zadajmy sobie pytanie, dlaczego Kościół Chrystusowy tak długo zwlekał z uznaniem praw człowie$\mathrm{ka}$, na które przecież dziś tak często powołuje się, i ich bron na równi z obowiązkiem przekazu Ewangelii. Chodzi o to, dlaczego historia "praw człowieka» jest krótsza od historii "prawa naturalnego" ${ }^{71}$.

\section{1. Przyczyny konfliktu Kościoła «z tak zwanymi» prawami czlowieka}

Chrześcijańskie pojęcie praw człowieka w relacji do tego - jak je rozumieli (ją) liberałowie - zostało ubogacone poprzez głębsze zrozumienie godności człowieka. ${ }^{72}$ Ostatecznie, to Sobór Watykański II położył pod "prawa człowieka» teologiczny fundament, stwierdzając iż to człowiek $z$ natury jest nakierowany na poszukiwanie prawdy, więc także $i$ na Boga. Dokonał się tym samym jakby przewrót mentalnościowy, jako że naturalne prawa człowieka stały się jednym $\mathrm{z}$ podstawowych argumentów na uznanie transcendentnej godności osoby wobec prawa cywilnego. To w konsekwencji oznaczało przyjęcie tego prawa jako podstawowego kryterium sprawiedliwości wszelkich norm prawnych stanowionych przez państwo.

${ }^{A}$ Por. PIUS IX, Encyklika Qunata cura, w: Pius IX pogromca liberalizmu, S. Krajski, Warszawa 2000 , s. $146-148$.

70 W epoce współczesnej deklaracje praw człowieka w mają swój początek wraz z Deklaracją Niezależności USA (1776 r.), która zakłada istnienie niezbywalnych praw. Wcześniej byly: Wielka Karta Praw dozwolona przez Jana bez ziemi, w 1215 r., oraz Konstytucja z Avili, w 1521 r; por. F. COMPAGNONI, I diritti dell'uomo. Genesi, storia e impegno cristiano, dz. cyt., s. 40.

i) Por. Tamże.

72 Por. Y-M. HILAIRE. Prawa czlowieka, prawa osoby, „Communio” 9 (1994) s. 212. 
Jeśli weźmiemy pod uwagę sam fakt i charakter Rewolucji Francuskiej, to nie może dziwić, że Magisterium Kościoła w «laickim» umocowaniu praw człowieka widziało zagrożenie i miało poważne obiekcje, co do ich akceptacji. ${ }^{73}$ Jeśli natomiast dziś dla obrony godności osoby ludzkiej (jej życia i do podstawowych wolności), chrześcijanie bardzo często odwołują się do tzw. praw człowieka, to trzeba zwrócić na motywację takiego działania. Otóż: «teologiczne uzasadnienie praw człowieka pozwala na stwierdzenie, że zaangażowanie się $w$ obronę godności i praw człowieka jest konstytutywną częścią świadectwa dawanego Ewangelii». ${ }^{74}$ Zatem, głoszenie praw człowieka wcale nie oznacza przyjęcia ich przez Kościół w jakiejś liberalnej formie. Jako przykład należy podać, że papież Pius XII długo nie wypowiadał się, co do Powszechnej Deklaracji Praw Człowieka, właśnie $z$ powodu jej laickiego charakteru. ${ }^{75}$

Chcąc wyjaśnić złożoność sprawy, trzeba powiedzieć, że nie wszystkie relacje międzyludzkie są i muszą być ujęte bezpośrednio w prawa człowieka. «Prawa człowieka - przynajmniej te klasyczne aż do Powszechnej Deklaracji Praw Człowieka z 1948 r. włącznie, odnoszą się do relacji pomiędzy jednostką a grupą i państwem, podczas gdy prawo naturalne, w licznych ujęciach dotyczyło każdego stosunku jednostki do innych jednostek» ${ }^{76}$. Wynika stąd, że przejście od "naturalnego prawa moralnego" do "praw człowieka» odbywa się za pomocą «naturalnych praw człowieka», które to stają się wyznacznikiem sprawiedliwości prawa cywilnego.

Chociaż prawa człowieka wynikają $\mathrm{z}$ naturalnego prawa moralnego, to ich historia nie jest jednakowa, dlatego że w epoce współczesnej idea praw człowieka opiera się z jednej strony na prawie naturalnym (różnie rozumianym), a z drugiej na przyzwoleniu społecznym. To tu znajduje się źródło ich ograniczeń: a) z prawnego punktu widzenia wszyscy ludzie są posiadaczami praw, ale niestety nie istnieje takie prawo, które gwarantowałoby, że każdy człowiek mógłby wyegzekwować swoje uprawnienia; b) jeśli nawet każdy człowiek jest podmiotem praw, to w rzeczywistości tylko obywatel (jako partner paktu społecznego), może domagać się od państwa ich respektowania. Innymi słowy: nawet gdy naturalne prawo moralne zostanie ujęte podmiotowo, stając się naturalnym uprawnieniem

73 Por. Tamże, s. 211: Zgromadzenie Narodowe «bez porozumienia z papieżem całkowicie reformuje Kościół francuski Konstytucja cywilną kleru (ogloszoną 12 lipca 1790 r.), a 7 listopada 1790 r. na wszystkich duchownych, którzy otrzymali urzędy cywilne, nakłada obowiązek składania przysięgi»; zobacz: A. SODANO, La Santa Sede nella comunita' internazionale, Watykan 2003, s. 29.

74 JAN XXIII, Pecem in terris, 64.

75 Por. F.J. MAZUREK, Interpretacja międzynarodowo chronionych praw cztowieka, „Ethos” 45/46 (1999) s. 244.

76 F. COMAPGNONI, Diritti dell'uomo. Genesi, storia e impegno cristiano, poz. cyt., s. 40. 
człowieka, to tylko $w$ sytuacji gdy zostanie sformalizowane przez ustawodawstwo państwowe - będzie tzw. "prawem człowieka», tj., uprawnieniem obowiązującym $w$ cywilnym porządku prawnym.

Także nie można zapominać, że moralność rozumiana jako wizja ułożenia stosunków społecznych i proponowana przez Magisterium, jest nie tylko integralną częścią ewangelizacji, ale także konkretną pomocą i podpowiedzią jak postępować, aby ułożyć pokojowe współżycie obywateli, czyli jak stworzyć środowisko przyjazne życiu. Nie jest to takie łatwe - może dlatego Kościół, chociaż był zawsze wierny idei naturalnego prawa moralnego, to dopiero w ubiegłym stuleciu (Sobór Watykański II), gdy opracował teologiczne uzasadnienie "praw człowieka», zaczął je bardziej propagować. ${ }^{77}$ Nie jest to proste także dlatego, że $\mathrm{w}$ obecnej erze władza publiczna wycofuje się $\mathrm{z}$ areny życia społecznego, wyrzekając się odpowiedzialności za jego kształtowanie, co oznacza prywatyzację sfery publicznej rozumianej jako przestrzeń społecznej kooperacji. Podstawowym ośrodkiem środowiska społecznego staje się prywatne życie jednostek. «Ludzie mogą efektywnie działać (...) jedynie jako osoby prywatne». ${ }^{78}$

\section{Wnioski}

Wydaje się, że z powyższych rozważań, można wysunąć następujące wnioski: Po pierwsze, nie należy zapominać, że autentyczne poszanowanie praw człowieka zależne jest od pojmowania godności osoby ludzkiej, a zarazem od idei sprawiedliwości, której treść jest uwarunkowana rozumieniem uniwersalnych wartości. Jak wiemy, we współczesnej praktyce prawnej, nie zawsze jest ona równoznaczna $z$ poszanowaniem pełnej prawdy o człowieku.

$\overline{77}$ O tym, że nieufność Kościoła do praw czlowieka wynikała z faktu, że ich pojęcie zostało opracowywane w środowisku świeckim i antyklerykalnym, świadczy choćby ten fakt, iż już w Średniowieczu mówiło się o tzw. ius gentium. Rozwój tej myśli mamy w Szkole Salamańskiej (XVI-XVII w.) gdzie z okazji odkrycia Ameryki, mówiło się o naturalnej godności człowieka i o prawach należnych każdej osobie (Las Casas, Suarez); Leon XIII w enc. «Rerum Novarum» mówił o prawie do zrzeszania się; Pius XI w encyklice «Divini illus» o prawie rodziców do wychowywania dzieci; w enc. «Mit brennender Sorge» w 1937 r., dotykał prawa do wolności religijnej; w enc. «Divini Redemptoris» proklamował godność i fundamentalne prawa czlowieka w ogóle; Pawel VI w enc. «Pacem in terris» w 1963 r., poruszal kwestię praw człowieka, a także praw politycznych; Sobór w deklaracji «Dignitatis Humanae» w 1965 r; deklarował prawo do wolności religijnej jako prawo wobec społeczności i państwa; w konstytucji «Gaudium et Spes» poruszył on problem praw człowieka, takich jak: ekonomiczno-społecznych, politycznych, sprawiedliwej wojny itp.

78 S. MICHALIK, Koncepcja wolności ponow'oczesnej w' twórczości Zygmunta Baumana, art. cyt., s. 53. 
Po drugie, jeśli nie dziwi nas powszechne uznanie zasady, że stosunek do praw człowieka jest podstawowym sprawdzianem legitymizujacym sprawiedliwość porządku społecznego, jako że uprawnienia owe maja swe źródło w prawie naturalnym i boskim objawionym (dlatego są one pojmowane jako niezbywalne, tj., ich wartość i treść jest w swej istocie niezależna od uznania państwowego), to smuci nas fakt, że pomimo tak licznych deklaracji o prawach człowieka, dochodzi ciagle do tak niesprawiedliwego jego traktowania.

Po trzecie, można zaryzykować twierdzenie, że jeśli nie dojdzie do jakiegoś wstrząsu moralnego, który doprowadziłby do zrozumieniu pojęcia nadprzyrodzonej godność czlowieka, a tym samym czym jest sprawiedliwość (spoleczna), to świat nie potrafi oprzeć się kulturze śmierci, szczególnie że ma ona za sobą oparcie w «strukturach grzechu». Po prostu, mówienie o przyrodzonej godności człowieka nie wystarcza, aby zabezpieczyć przyjazne środowisko życia osobie ludzkiej.

\title{
Christian Social Justice as the Direction for the Development of a Friendly to Life Environment
}

\begin{abstract}
SUMMARY
Justice (perfection) of a democratic law-abiding State expressed as an environment of social life: this is an issue, that very frequently is present upon the lips of jurists, politicians, political scientists, legislature members, but also: ethicists, bioethicists, moralists, theologians, and others. This subject has been also taken for reflection because of the fact, that we are living in such a system, and more: we must struggle with many problems, which make one ask: is the democratic system that is being constructed founded on sufficiently healthy foundations, so that it may be possible to say that we are all equal in relation to the law being passed and that its principles are just? So we have taken up here an ethical reflection on the subject of the philosophy of law and State (that is: philosophy of care for our life environment) predominant in the European Union, the directives of which, coming from different treaties and agreements, are being applied to our home legislature. The main axis, around which our reflections were developed, were the basic principles of the Christian concept of social justice. These are the basis for interpersonal and international dialogue. These principles are: «peace», "solidarity», "justice", "freedom», «truth" and «love». The main conclusion stemming from this article is: in the concept of State and law of today there is a lack of a permanent point of reference, and this point of reference should be the principle of social justice based on objective truth.
\end{abstract}

